University of Wollongong

Research Online

Faculty of Social Sciences - Papers (Archive) Faculty of Arts, Social Sciences \& Humanities

2013

Policy advocacy organizations: A framework linking theory and practice

Sheldon Gen

San Francisco State University

Amy Conley Wright

University of Wollongong, acwright@uow.edu.au

Follow this and additional works at: https://ro.uow.edu.au/sspapers

Part of the Education Commons, and the Social and Behavioral Sciences Commons

Research Online is the open access institutional repository for the University of Wollongong. For further information contact the UOW Library: research-pubs@uow.edu.au 


\title{
Policy advocacy organizations: A framework linking theory and practice
}

\begin{abstract}
The practice of policy advocacy by organizations has outpaced its theoretical development. Yet the importance of a theoretical grounding for advocacy campaigns has increased with the need for accountability and an understanding of advocates' contributions to policy development. This article synthesizes practitioner and academic literature on policy advocacy and proposes a conceptual framework of policy advocacy inputs, activities, and outcomes. Five distinct advocacy strategies are hypothesized: enhancing a democratic environment, applying public pressure, influencing decision makers, direct reform, and implementation change. This framework provides guidelines for organizations to strategically engage policy processes, while directing a research agenda on advocacy organizations.
\end{abstract}

\section{Keywords}

policy, organizations, framework, linking, theory, practice, advocacy

Disciplines

Education | Social and Behavioral Sciences

\section{Publication Details}

Gen, S. \& Wright, A. C. (2013). Policy advocacy organizations: A framework linking theory and practice. Journal of Policy Practice, 12 (3), 163-193. 
RUNNING HEAD: A FRAMEWORK FOR POLICY ADVOCACY

Policy advocacy organizations: A framework linking theory and practice 


\begin{abstract}
The practice of policy advocacy by organizations has outpaced its theoretical development. Yet the importance of a theoretical grounding for advocacy campaigns has increased with the need for accountability and an understanding of advocates' contributions to policy development. This article synthesizes practitioner and academic literature on policy advocacy and proposes a conceptual framework of policy advocacy inputs, activities, and outcomes. Five distinct advocacy strategies are hypothesized: enhancing a democratic environment, applying public pressure, influencing decision makers, direct reform, and implementation change. This framework provides guidelines for organizations to strategically engage policy processes, while directing a research agenda on advocacy organizations.
\end{abstract}

Keywords: Advocacy, public policy, logic model 


\section{Introduction}

Civic participation in policy advocacy is varied and complex, and ways to simplify it are helpful for creating understanding. Its complexity mirrors the policy making process itself, with interacting considerations such as lengthy time span, difficulties of attributing success to a particular advocacy effort, and the central role of values (Sabatier, 1999). However, little in the academic literature directly and holistically addresses the theoretical linkages between policy advocacy activities by the public, their requisite resources and knowledge, and their expected outcomes. The practitioner literature has begun to address this gap by identifying policy advocacy inputs, activities, and outcomes. Yet the utility of this information is limited without some reasoning or evidence of how inputs lead to activities, or activities to outcomes. How should an advocacy organization make decisions about investing in resources, such as staff, training, and materials, without knowing what these inputs may enable? And why should advocacy organizations engage in particular activities, without knowing the potential associated outcomes? At a practical level, the lack of knowledge in this area hinders effective advocacy programs. At an academic level, the lack of a conceptual framework limits understanding of the various aspects of advocacy programs and their role in the policy making process.

This article responds to the need to understand policy advocacy as a systematic process, to enable measurement and evaluation (Hoefer, 2011). It attempts theory building through the development of a conceptual framework, understood as a set of variables and how they interrelate, with directionality among relationship not requisite, but possibly hypothesized (Ostrom, 1999). The article does so by synthesizing the professional literature on policy advocacy with the academic literature, primarily drawn from policy studies, to formulate an empirically testable model for policy advocacy. 


\section{The context of policy advocacy and its problem}

We must first begin with a common understanding of what we mean by policy advocacy. While the academic literature on specific forms of policy advocacy is easily identifiable (e.g., lobbying, media work, campaigning, etc.), the broader concept has escaped critical attention. Reid (2001) notes that advocacy is something we recognize when we see it, but lacks definition: "There is no agreement on which activities constitute advocacy, and no one source gives a full account of the many kinds of activities and strategies groups use to leverage influence in the policy process." (p. 2). The absence in the academic literature of a common understanding of the forms, contexts, elements, dynamics, and markers of effectiveness of policy advocacy make this a challenging concept (Arons, 2000). Moreover, looking to the work of policy advocates reveals a complex array of activities related to policy advocacy, with assumed and tenuous connections to potential outcomes.

However, when we look to how the term policy advocacy has been used in the academic and professional literature, some defining characteristics emerge. First, policy advocacy is initiated by citizens, acting individually or as a collective (Reid, 2001) often represented by nonprofit organizations (Reed, 2006). The citizens represented may have less relative power in society or may be unable to represent their own interests, such as the poor or children (Jansson, 2010; Schlozman \& Tierney, 1986). This "bottom up" approach initiated by citizen stakeholders (Rietbergen-McCracken, n.d.) lies in stark contrast to "top-down" public participation activities that are initiated by government bodies, including familiar outreach tools such as public hearings, citizen surveys, citizen juries, etc. (McLaverty, 2011).

Second, the method of policy advocacy involves a deliberate process (Sprechmann \& Pelton, 2001) of influencing decision makers (Jenkins, 1987) or influencing a social or civic 
agenda (Schmid, Bar, and Nirel, 2008) in order to build political will around action

(Grantmakers in Health, 2005). Specific advocacy approaches described by Hopkins (1992) include: programmatic (or issue) advocacy, when an organization takes a position on a public policy that affects their work; legislative advocacy, or lobbying of legislators; political campaign activity to support or oppose political candidates; demonstrations, rallying public support around an issue or policy; boycotts, to encourage or discourage business with a targeted entity; and litigation, or using legal action to advance a cause. McCarthy and Castelli (2002) add to this list grassroots advocacy, or engaging individual citizens in an advocacy effort. While some also consider capacity building to be policy advocacy (Morariu et al., 2009), we deliberately left out those elements in the logic models when they were not connected to a goal of policy or social change.

Finally, the aim of advocacy ultimately is a change to policy (Reisman, Gienapp \& Stachowiak, 2007) or the policy making process, generally to make it more accessible and transparent to the public; this latter goal has been called "participatory advocacy" rather than policy advocacy (Chapman \& Wameyo, 2001). In terms of policy change, the goal may be to adopt, modify, or reject certain policy options (Moore, 2011). Thus, to summarize the main characterizations across the academic and professional literature, for our purposes in this study, policy advocacy is defined as intentional activities initiated by the public to affect the policy making process.

\section{The purposes of policy advocacy}

When considering the general purposes of policy advocacy in a democratic society, the broader literature on public participation provides both normative and descriptive answers. On the normative side, public participation is widely prescribed to legitimize the process of policy 
making. By providing the public access to the process, the public's input can at least complement the government's prescriptions for rational approaches to decision making (deLeon, 1992) and perhaps identify shared interests between the two (Denhardt \& Denhardt, 2000). In doing so, public commitment (Bryson \& Anderson, 2000), and perhaps consensus (Xu, 2001), for policy choices are enhanced. On the descriptive side, a limited body of empirical research conclude that public participation can produce better policy outcomes. Policies developed with public input have been found to be more effective (Kastens \& Newig, 2008), have wider distributions of benefits (Gallagher \& Jackson, 2008), and be more valued by the public (Smith \& Huntsman, 1997). Furthermore, others have found that public participation can also improve the government processes itself, by making them more responsive to public concerns (Frederickson, 1982; Nalbandian, 1999) and more adaptive to their changing environments (Koenig, 2005).

While these benefits are impressive, they are social, and they ignore the fact that advocates often engage the policy process not for broad social gain, but to advance their own specific preferences. That is, while the above benefits of public participation accrue to society, the individual groups of advocates may engage policy for more narrow benefits. It is doubtful, therefore, that the social benefits of a lively campaign among competing interests would be enough to motivate advocates to participate. What is entirely missing from the academic literature are the benefits to advocates for their policy advocacy efforts. What are policy advocates' expected outcomes for engaging the policy process?

The simple answer to this question is they seek favorable policy outcomes. After all, policy advocates often advocate for specific policies. However, this answer does not hold up against thoughtful scrutiny. First, if this were the sole measure of success for advocacy efforts, 
then most could only be called failures. In a pluralistic society, few get exactly what they want in policies. Especially with controversial issues that attract deep engagement by many advocacy groups with different preferences, the policy outcome is seldom a zero-sum game with clear winners and losers. As Robert Salisbury described, "Very often there is no clear resolution, no definitive conclusion to the process by which interests are articulated and pursued. 'Play' continues..." (cited in Baumgartner \& Leech, 1998, p. 61). Additionally, even in those rare cases where a policy advocacy group gets its preferred policy, attribution of that outcome to their own advocacy efforts is tenuous at best. Other groups with overlapping preferences may have contributed to the outcome, making the causal link between advocacy efforts and outcomes difficult, if not impossible, to empirically establish (Baumgartner \& Leech, 1998). Further complicating the issue is the temporal length of political processes. The arc of policy change can be on the scale of decades for some issues (Sabatier \& Jenkins-Smith, 1999), an order of magnitude longer than advocacy organizations' programmatic and budgetary cycles. Activities with such long feedback loops are not as attractive to supporters as those with more immediate impacts.

In practice, there are ranges of expected outcomes for advocacy efforts, of which favorable policy change is just one. However, while the practice of advocacy has advanced, its theoretical groundings have not. This is certainly not for a lack of theories of policy processes, but for a lack of application to policy advocacy. This review begins to fill this gap in the literature by focusing on three related questions: 1) what do policy advocates do to try to affect public policy, 2) what are their requisite inputs to perform these activities, and 3) what are their expected outcomes for their efforts? The answers to these questions have both practical and theoretical significance. First, demand for accountability in advocacy work has grown. Policy 
advocates and their supporters - from individual donors to major grant funders—-want to see measurable results of their advocacy efforts (DeVita, Montilla, Reid \& Fatiregun 2004; Fagen, Reed, Kaye, \& Jack, 2009). Short of favorable policy change, what other benchmarks might reflect the success of advocacy efforts? Second, as described later in this article, theories of policy processes may hypothesize the links between types of advocacy activities and specific effects. This could help practitioners to strategically plan their advocacy efforts, broaden the applicability of existing theories, and guide future research in policy advocacy.

\section{Methods}

This review draws on practitioner as well as academic literatures. Initially, materials developed by sources such as foundations and nongovernmental organizations were identified by searching Google and other mainstream search engines, using the search term 'policy advocacy' plus 'logic model.' Logic models are visual depictions of social programs or change efforts (Knowlton \& Phillips, 2009). Some of the logic models led to the discovery of others, by checking their references. For inclusion in the study, logic models had to focus on policy advocacy and include at minimum the categories of inputs, activities, and outcomes (some logic models described this latter category as goals, indicators, short and long-term outcomes, or outcomes and impacts). The elements of the logic model could be provided in a graphic, tabular, or narrative format. Reports that describe how to construct a logic model and use it for advocacy evaluation purposes, but did not identify concrete elements of a policy advocacy logic model (for example, Guthrie, Louie, David \& Foster, 2005) were excluded from the study. By the time six logic models were found, themes identified in the logic models became repetitious and we determined that saturation of ideas had been reached (Glaser \& Strauss, 1967). See Table 1 for the list of logic models included in the study. 
The scope of the logic models, in terms of focus on special advocacy topics and organizational authors, is broad. A number of the logic models identified were created by or at the behest of foundations, including the Annie E. Casey Foundation, California Endowment, and Grantmakers for Health. Two of the organizational authors focus on evaluation: Center for Community Health and Evaluation and Innovation Network, Inc. One organization, Action Aid, is an international humanitarian aid organization. Given the saturation of ideas and variety of sources, we concluded that an adequately representative sample (Cooper, 1988) of policy advocacy logic models had been identified.

Next, these policy advocacy logic models were combined into a composite table through a process of coding each logic model for shared themes (Table 1). This table is most akin to a theory of change, given its simplicity and purpose of explaining how social change is expected to occur; by contrast, a program logic model is intended to be comprehensive and outline the connections needed for a evaluate or monitor a social program. However, as the combined model was adapted from practitioner logic models, it includes elements more commonly found in program logic models than theory of change models (Knowlton \& Phillips, 2009). In this paper, we refer to this table as a "combined logic model." Its unit of analysis is the advocacy program or campaign that an organization engages, and it has three major categories of elements: inputs, activities, and outcomes. The breadth of activities we identified captured all those identified by Baumgartner and Leech's (1998, p. 152) comprehensive review of interest group activities, further confirming the adequate scope of our sample of logic models. The category of outcomes includes three levels: proximal (near-term and more direct), distal (long-term and more indirect) and impacts (intended change). Abbreviations are included in our descriptions to indicate the original logic models from which the elements are drawn. 
This task of combining logic models was guided by our expectation that there are common sets of inputs, activities, and expected outcomes for policy advocacy programs that transcends specific policy outcome goals. Still, the authors of the original logic models developed them under different contexts that required us to interpret some elements in the original logic models differently that the original authors had. For example, the logic model developed by Action Aid was intended for advocacy work in developing democracies. Thus, the activities they identified had goals of building democratic capacities and processes, rather than specific policy outcomes. Meanwhile, other logic models were developed in a U.S. context that assumed that democratic processes are in place. Thus, their logic models identified activities that aimed to change policies in specific fields (e.g., health, family welfare, etc.). We coded the logic models from a perspective of a functioning democracy characterized by "free elections for a popular mandate, with elected officials held responsible to the citizenry; the existence of an effective, independent judiciary; a depoliticized bureaucracy functioning according to written rules; legal guarantees (usually of a constitutional nature) of basic rights; and a free press" (Ramet, 1992, p. 549). From this perspective, we independently coded the elements of the logic models, using inductive and deductive processes to identify key ideas. Codes were created and grouped until central themes emerged (Glaser \& Strauss, 1967), and complete coding agreement was achieved on the final round of coding.

Once the coded elements for the combined logic model had been identified (see Table 1), we turned to the academic literature to seek theoretical support for the elements in it and connections between them. Specifically, we sought theoretical connections between 1) inputs and the advocacy activities they facilitate, and 2) advocacy activities and their expected outcomes. The combined logic model headings (and variations of the concepts) were used as 
search terms in major academic databases, including Academic Search Premier, Lexus/Nexis, and ProQuest. In addition, major policy theories were reviewed for their relevance, drawing on mainstream policy texts. On the basis of this review of literature, Table 2 was compiled with speculated connections between logic model elements.

The rest of this article describes the elements of our combined logic model for policy advocacy, the theoretical links between its elements, and the proposal of a conceptual framework and its advocacy strategies linking inputs, activities, and outcomes, based on our review of relevant theories.

\section{[Table 1 about here]}

\section{The combined logic model and its theoretical support}

Based on its utilization in the practitioner literature, logic models appear to be a useful way of understanding the process of policy advocacy. Hoefer (2011) recommends a procedure called "advocacy mapping," based on a logic model approach, to plan the steps of an advocacy effort, systematically connecting the problem or issue of focus and desired outcome with the resources, tasks, outcomes, and ultimate social justice societal outcome. Using a logic model approach offers the advantage of determining the desired outcomes of an advocacy effort at the outset, to encourage clear connections between advocacy strategies and goals.

To be plausible, the hypothesized connections between elements of a theory of change or logic model require an underlying foundation of theory and research, rather than just assumptions or anecdotal evidence (Knowlton \& Phillips, 2009). Yet none of the sources of the combined logic model identified connections between logic model elements. In this section, relevant theories are identified, applied, and interpreted in the context of public policy advocacy. 
In some cases, application involves extrapolation, as theories originally devised in other contexts are extended to advocacy.

[Table 2 about here]

Linkages between inputs and activities. The first category of the combined logic model is labeled 'inputs.' In program logic models, this category is often described as resources required or consumed by activities (Knowlton \& Phillips, 2009). In this context, inputs are those necessary conditions for policy advocacy activities.

One input identified by the review of practitioner logic models is a sense of agency or empowerment by would-be advocates that allows them to feel that their actions may have an impact upon the public policy making process. Empowerment theory, a psychological construct used in fields including community development, public health, social work, and organizational management (Perkins \& Zimmerman, 1995) fits with this notion, most particularly as it is used in the field of community psychology. While empowerment is often defined imprecisely, it evokes the connections between the strengths and competencies of community members, natural helping systems that exist within communities, and their potential to impact social policy and create social change (Rappaport, 1981). It encompasses both attitudes and behaviors, by connecting how one understands one's competence and efficacy and how one chooses to act in social and political arenas. A central idea is the connection between perceived personal control and behaviors that seek to exert control (Zimmerman, 2000).

In terms of application, empowerment theory is most relevant to grassroots advocacy, as the premise is that empowerment exists not when community members are dominated by professionals in a top-down manner, but when the people inform officials of what social policies and programs are needed in a bottom up manner (Elmore, 1979). In other words, enacted 
empowerment allows people to exert control over their own lives, rather than cede control to professionals or decision makers (Rappaport, 1981). Since empowerment is perceived as a characteristic of communities or groups, as well as individuals, it may lead to collective forms of action (Zimmerman, 1995), such as engaging the public and connecting with allies. An empowered community is understood to have well-connected organizations, in the form of coalitions, as well as venues for citizen participation, such as neighborhood crime prevention councils (Zimmerman, 2000).

Empowerment theory holds implications for the second input identified, specialized knowledge and skills (Rappaport, 1981), suggesting that skills are best developed in the context of daily life rather than in specialized training programs that lack real world application (Rappaport, et al., 1975). Given that policy advocacy is a set of tasks intended to make a change at national or societal level, the primary 'input' needed is able advocates. The review of logic models identified various forms of specialized knowledge and skills necessary to engage in advocacy efforts; these include an understanding of strategy, research, media advocacy, public relations, and lobbying. Though there is no clear consensus (Strebler et al., 1997; Jubb and Rowbotham, 1997), the concept of 'competency' has many meanings, including a person's underlying skills, knowledge, and abilities as well as actions and behaviors that can be observed (Hoffman, 1999). This concept has taken root in many fields, including psychology (to measure ability and how observable behaviors reflect underlying traits); management theory (to define how organizational goals are achieved); human resource management (to assess process of recruitment, training, etc.); education (to link work preparation and professional advancement with education); and political science (to improve efficiency of labor markets) (Hoffman, 1999). The concept of competency applied to policy advocacy connects the 'input' of people and their 
specialized skills in strategy, research, media, public relations, and lobbying, with 'activities' that require such skills, such as connecting with allies, engaging with the public and people in positions of power, and conducting information campaigns. Indeed, competency is often understood, particularly in the American research literature, as an 'input' consisting of attributes possessed by an individual (Boak, 1991; Burgoyne, 1988; Rowe, 1995; Tate, 1995; Woodruffe, 1991).

People and the relationships between them seem to be considered as crucial inputs to the advocacy process. The players in advocacy may be paid administrators and staff, as well as volunteers and strategic partners. Social capital theory suggests that qualities inherent to relationships, like trust and reciprocity, can allow members of networks to benefit from their bonds with each other (Lin, 2001). Robert Putnam's (2000) work on social capital, with its focus on civic participation and political life, is most relevant to policy advocacy. He makes a distinction between two types of social capital: "bridging" and "bonding." Bridging social capital brings together people from diverse backgrounds; examples include the civil rights movement and ecumenical religious organizations. Bonding social capital, found in fraternal organizations and country clubs, encourages group identification and exclusivity. Both are highly relevant for advocacy; the former in particular for engaging the public, and the latter for connecting with allies. The notion that social capital could be broken down into 'weak' ties among acquaintances and 'strong' ties among friends emerged from Granovetter's (1973) research on how people use social networks to find jobs, and has been applied to use of social media in social activism (Gladwell, 2010).

Tangible financial and material resources are also noted as necessary inputs to the advocacy process. The role of financial and material resources is a facet of resource 
mobilization theory. Resource mobilization theory posits that engagement in social movements depends on factors related to the circumstances of potential participants, including their competing commitments, resources, social support, and costs (McCarthy \& Zald, 2002). There are two strands of the theory that have emerged; one that focuses on the political process (McAdam, 1982) and another on organizations and entrepreneurship (McCarthy \& Zald, 1973). In terms of resources, social movements require "land, labor, and capital" (Tilly, 1978, p. 6) to flourish, and groups lacking in these resources will struggle to organize and find success. Additional theoretical refinement suggests a typology of moral, material, human, and informational resources (Cress and Snow, 1996). Resources may be located in the group, allied groups, and larger society. Social movements with shared goals can combine into "industries" that can share resources, particularly through shared technologies of mobilization and protest; however, they also compete for limited financial resources from supporters, such as foundations, and may clash over leadership decisions (McCarthy \& Zald, 2002).

In terms of policy advocacy, resource mobilization theory has a few major implications in terms of activities. It identifies media access as a resource and suggests that social movements depend upon and attempt to shape media coverage to reach a larger public. It also suggests that groups can better meet their missions when they combine together with others in coalitions, or “social movement industries" (McCarthy \& Zald, 2002). Those in position of authority can be assets to a social movement, if they become adherents and elevate a cause in the view of authorities (McCarthy \& Zald, 1977). This theory also suggests an association between financial resources and successful advocacy, because these resources enable the hiring of expert staff and the execution of communications campaigns (McCarthy and Zald, 1977; Saidel, 2002) that are central to policy advocacy. Organizations with higher revenue and larger numbers of staff may 
also have greater organizational capacity to engage in a wide array of policy advocacy activities (Child \& Gronbjerg, 2007).

In summary, the theories and concepts of empowerment, competency, social capital, and resource mobilization support connections between the inputs and some of the activities identified in the logic model, in particular: connecting with allies; engaging the public; engaging people in positions of power; and information campaigning (see Table 2).

Linkages between activities, outcomes, and impacts. We next turn our attention to advocacy activities, and apply relevant policy theories to predict resulting outcomes, both near term and long term. Activities are defined here as the concerted actions done in advocacy that are meant to affect policy processes. The range of activities noted in the logic models suggest that advocates have an extensive menu of options for seeking their policy advocacy goals, which include strategies that aim to engage, inform, and influence other advocates, decision makers, and the public. These activities may result in short-term/proximal outcomes that create an opening for social change, such as responsive democratic environment that enables advocacy, greater public awareness and support of an issue, and decision maker awareness and support. The long-term or distal goal of public policy advocacy is, of course, affecting change in the policy domain through policy adoption and changes to policy implementation. Ultimately, policy itself is a means to an end, and that end is societal impact (Knowlton \& Phillips, 2009), whether on people, services and systems, or the political system (Chapman \& Wameyo, 2001).

The first two types of activities in the combined logic model—coalition building and engaging the public - share a common characteristic of coordinating with organizations and individuals with similar policy goals. These types of activities assume a pluralistic view of democracy (Dahl, 1967) in which policy power is dispersed among many competing groups and 
interests. In this view, an organization's own policy preferences are more likely to be enacted if greater support for them can be demonstrated. Thus the theoretical literature on coalitions, issue networks, and interest groups most directly apply here. Most relevant, the advocacy coalition framework claims that policy subsystems, made of participating coalitions of interests, is the most relevant unit of analysis for understanding policy change (Sabatier, 1988), even more so than government players, because it is the coalitions within these subsystems, and their interactions with each other, that drive policy change. Furthermore, these coalitions are formed around common policy beliefs and interests, and their goals are to translate those beliefs into public policies (Nowlin, 2011; Sabatier, 1988; Sabatier \& Jenkins-Smith, 1999). They attempt to do so through exchanges of information and views among the coalitions, resulting in relevant learning about the policy issue, and changes in policy preferences. Thus, the theory appears to link coalition building, public engagement, and information campaigning to changes in the public's and decision makers' awareness and support, leading further to policy change. The advocacy coalition framework originated from observations of environmental policy change, but has since been applied to numerous policy issues (Weible et al., 2011). Complementing this framework are interest group studies that describe the characteristics of groups that affect their relative influence on policy (Baumgartner \& Leech, 1998). These focus on include their ability to coordinate collective communication and mobilize members for actions (Cahn, 1995, p. 208), their size (e.g., membership, budgets) and expertise (Cahn, 1995, p. 208; Sabatier, 1988), and their status or prestige in the policy issue (Truman, 1993).

Despite these promises of coalition building, mobilizing the public to act is difficult and has drawn its own attention in policy studies. Olson's (1965) theory of latent groups claims that large groups are ineffective (latent) in achieving common goals unless the individuals in them 
are coerced or induced to act. Thus, in policy advocacy, large groups of engaged citizens must be mobilized to vote, protest, rally, etc., because most individuals in the group will not on their own. The purposes of such mobilization may depend upon the specific organized activity. For example, protests are meant to draw attention to specific issues, to spur policy actions. Thus, they can be seen as focusing events to set the policy agenda (Birkland, 1997; Kingdon, 1984). While academics have mostly limited their studies of focusing events to natural disasters (e.g., draughts, hurricanes, tsunamis) and human accidents (e.g., nuclear power plant meltdowns, levy breaches), focusing events can be human-made. Protests and rallies are examples of these.

In general, mobilization activities at a minimum increases the capacities of individuals in the policy process. Putnam (1976) identified a stratification of policy power with six levels, ranging from bottom to top: nonparticipants, voters, attentive public, activists, influentials, and proximate decision makers. One purpose of mobilizing the public, therefore, could be to move individuals to higher strata of policy influence. Indeed, one normative criticism of this stratified, elitist policy power structure is the lowest strata support elitism by not participating in the process (Walker, 1966). Through inaction, nonparticipants tacitly delegate their authority to the existing power holders. In contrast, developing broader participation in the lower strata essentially redistributes power more equitably across the strata.

In contrast to engaging the public to build broad based support is a set of advocacy activities that focus on building support within small groups of key policy players. This type of activity—including lobbying and building relationships with decision makers—evokes the view of institutionalism in which power to change policy is wielded directly by those formal players who are required to participate in the policy process: legislatures, executives, courts, and even government agencies (Cahn, 1995; Theodoulou \& Kofinis, 2004, pp. 55-77). While engaging 
those who are required to participate and have direct influence seems like an obvious advocacy strategy, rival theories of the policy process do not place primary power with the institutional players. Instead, they view the decisions and the actions of institutional players to be reactions to more powerful, noninstitutional players that influence them. In institutionalism, however, policy advocates attempt to influence the formal players directly, rather than through public pressure, media, or other intermediate players.

Still, advocacy work with key policy players is not limited to institutional players. There may be powerful individuals or groups, inside and outside of government institutions, that dominate the policy process, and policy advocates may attempt to build relationships with them in order to influence policy. Elite theory substantiates this strategy. It claims, like institutionalism, that policy power is concentrated in a relatively small group of people. But unlike institutionalism, that group is not necessarily government players. Instead, they are an upper social class of people who are relatively homogenous, self-aware, and self-perpetuating (Mills, 1956; Putnam, 1976). Advocates holding this view of power distribution conclude that any policy change necessarily requires the actions of the elite. Thus, educating them on issues and swaying their preferences is a proximal goal towards policy change. Admittedly, elite theory itself does not leave much room for non-elite advocates to influence the elite class. In fact, a tenant of elite theory is their relative autonomy (Putnam, 1976) and their ability to mold the opinions of the public to follow their own (Edelman, 1964; Herman \& Chomsky, 2002). Even so, in Putnam's (1976) pyramid of political stratification, he opens the possibility of the elite class being influenced by the activists and public below it.

The next category of advocacy activities, information campaigning, is supported by a broad range of expected outcomes identified by academic theories and empirical evidence. We 
divide this literature into two categories: one based upon the types of information produced for policy advocacy, and one based upon a particular mode of dissemination. In turn, the types of information can be further divided into two broad categories: research and rhetoric. Research activities in this context includes the analysis of empirical data as well as the construction of arguments based upon rationality (e.g., the practices described in Bardach, 2000; Weimer \& Vining, 1992). Indeed, many theories of policy decision making are derived from the classic normative theory of rationality. In this view, research and analyses play an important role in policy processes by providing relevant information to produce better decisions (Lindblom \& Cohen, 1979; Weiss \& Bucuvalas, 1980). Thus, some advocacy groups—especially think tanks - engage in policy research to inform stakeholders of relevant information needed for optimal policy selections. The audiences of the research may range from the decision makers themselves, for direct influence on policy change, to the at-large public, for indirect influence. Rationality as a descriptive theory, however, has come under unrelenting empirical criticism. Many have observed the sub-optimal realities of policy decision making and derived more grounded theories, such as Lindblom's incrementalism (1959) and Simon's (1945) bounded rationality and satisficing. Even so, these theories assume a normative desire for rationality, so research remains a vital aspect of these theories. Even normative critics of a rational approach to decision making do not refute the role that research can play. They simply don't give it the place of honor that it finds in rational approaches (e.g., Stone, 2002).

The other major category of information campaigning is rhetoric, carefully crafted language meant to persuade. Products of rhetoric used in policy advocacy are varied, but a few are supported by academic research. For example, framing is the practice of presenting an issue from a particular perspective that supports the framer's preference. Schneider and Ingram (1993) 
found that framing policy targets in a favorable light is an effective tactic for gaining policy support. They described this practice as the social construction of policy target populations in favorable light to increase policy support. Anecdotes, in contrast, are stories that convey policyrelevant information (Nowlin, 2011) that help audiences better understand the contexts, stakeholders, and values surrounding a policy issue (Jones \& McBeth, 2010). So far, the academic literature on rhetoric in policy advocacy lacks an overarching theory of impact, but the individual studies of specific rhetorical tools appear to mostly aim to change people's perspectives and understandings of policy issues.

Turning from the creation of information to its dissemination, media studies provide a wider range of expected outcomes for policy advocates. Overall, mass media are engaged by advocates for the obvious reason of raising public awareness of, and support for, advocates' issues (Nowlin, 2011). But some researchers have identified more specific outcomes. Iyengar and Kinder (1987), for example, found that issues covered by mass media can set the policy agenda by drawing public attention to it. Similarly, Linsky (1988) found that media coverage of policy issues raises the issue to higher levels of policy makers and increases their political will to act on these issues. He also found that media coverage can shorten the time for policy change.

Policy advocates can also attempt to more directly and actively reform policy. The most direct path is through litigation, which can force the judiciary to review the advocate's case and applicable policies themselves. Litigation as an advocacy tool is based less on academic theory as it is on judicial process. However, as an advocacy strategy that tends to be pursued by groups, scholars have considered activism through judicial channels to be a type of group pressure. Epstein and colleagues (1995) conclude that the decision making process of whether to pursue litigation as a strategy relates to the internal features of a group, the external social/political 
environment, and the perceived interplay between these. Key internal features include: the autonomy of group leaders to make decisions on the use of litigation; resources (money, time, staff, and contacts), with litigation requiring significant financial expenditure and time; organizational maintenance (or efforts to sustain the organization's existence), in terms of how the organization's constituency views litigation; and the foci or interests that the advocacy group is positioned to promote or defend, with organizations focused on issues such as discrimination and good governance tending to make greater use of litigation. The external environment is the broad social/political context, and whether it is favorable, unfavorable, or malleable (not yet decided) on the issue. The final decision of whether to act through litigation comes down to perceived institutional and organizational reasons. Acting through the courts can be an appropriate institutional avenue to achieve goals, such as under circumstances when groups perceive that they do not have influence in the executive or legislative branches. For organizational reasons, litigation may be an attractive approach due to availability of attorneys, the value of publicity for the organization, and the opportunity to challenge ideological opponents.

Overall, the study of group litigation has been criticized as being overly focused on examining substantive issues and failing to produce generalizable theory (Epstein, Kobylka \& Stewart, 1995). Still, adversarial legalism has been advanced by Kagan $(1991,1999)$ as a theory of the role of the courts in the policy making process, focused less on groups than on the (perhaps uniquely American) role of aggressive lawyers. One emphasis of this theory is on litigant activism, with claimants represented by lawyers, asserting their claims with the support of evidence. According to this theory, the upside of litigation is the opportunity for "have nots" to triumph, while the downside is the cost (in terms of time and money) and the uncertainty of 
outcome (due to fragmented legal authority and variability of the courts) (Kagan, 1999). While Kagan favors European approaches that put more policy control in the hands of bureaucrats, others defend the role of the courts in the policy making process as promoting balance among policy making authorities (Busch, Kirp, Schoenholz, 1998-9).

Pilot or demonstration projects are another way advocates may try to reform policies and programs, and their use is supported by incrementalism. Lindblom (1959) first identified incremental decision making in a negative light, as "muddling through," in which comprehensive rational decision making is abandoned in lieu of low-risk, low-impact decisions based upon series of "successive limited comparisons." According to Lindblom, this approach is taken because the necessary information and institutional support for comprehensive rational analyses are often lacking. He was describing a sub-optimal decision making process, not prescribing one. But low-risk incremental decision making can be an effective strategy for policy advocates when high-risk comprehensive reforms are political infeasible. In such cases, pilot projects can demonstrate the efficacy of a reform on small scales, thereby building support for more comprehensive reforms without imposing high risks to stakeholders. Thus, pilot projects can be seen as a strategic use of incrementalism to advocate for larger policy changes.

The defensive activities in the combined logic model assume a pluralistic democracy (Dahl, 1967) in which policy making influence is distributed amongst multiple competing factions. In this setting, engaging opposing factions in public discourse or debate is necessary to counter or lessen the oppositions' influence. The public dialectic among the factions transforms observers into informed stakeholders, influencing their perspective on the issues and perhaps gaining their alliance (Majone, 1989). For example, in the advocacy coalition framework, policy change follows policy-oriented learning among participants in the policy subsystem. Such 
learning refers to enduring changes in participants' understandings of the issues and their values placed on them, and the learning occurs through the exchange of information and views among policy participants (Sabatier, 1988). Operationally, this could include varying forms of public debate.

Activities that monitor policy implementation may serve different purposes for policy advocates. On one hand, they may be used to apply pressures on government agencies to implement policies as adopted. This function adopts the bottom-up view of policy implementation, in which bureaucrats have substantial discretionary power to interpret and apply policies as they see fit (Hill \& Hupe, 2011). Bardach (1977) and Pressman and Wildavsky (1984) famously described how bureaucrats and bureaucracies can thwart best intentions of adopted policies. In this view, bureaucrats are effectively policy makers themselves (Lipsky, 2010). Thus, savvy policy advocates may recognize the opportunity to influence bureaucrats' implementation activities by holding them accountable to the advocates' preferences in the adopted policies (Riley \& Brophy-Baermann, 2006). On the other hand, monitoring can be viewed as an evaluation activity, meant to measure and judge how well adopted policies are achieving their goals. The purpose here is to improve policy, though sometimes it is used as a symbolic act to appease stakeholders (Nachmias, 1980). For policy advocates, each of these outcomes may be relevant: the former to change policy, the latter to defend policy. But in both cases, the target of their advocacy is not the bureaucrats directly, but the policy agenda. That is, the monitoring is meant to get the policy back on the agenda for reform, or keep it off the agenda to maintain its current form.

The academic literature applied above all focus on the elements of our combined logic model that are advocacy activities, projecting what advocacy outcomes might be expected from 
them. Complementing this are a few theories from the policy studies literature that focus on specific outcomes in the combined logic model, and identify their antecedents. These too can help understand what policy advocates expect from their efforts. First, Kingdon's (1984) multiple streams theory describes how policy change can occur when three streams of events converge: a problem stream in which a social problem ascends the policy agenda, a policy stream that identifies solutions to the problem, and a political stream that dictates the political feasibility of policy change at a given time. The theory opens up several points of access for advocates to influence policy change. Indeed, each of Kingdon's streams might be influenced by activities in the combined logic model. For example, information campaigning can build public awareness of a problem, or promote a favored solution. Similarly, citizen mobilizations, such as protests, can serve as focusing events that builds awareness of a problem and sets the policy agenda. Also, lobbying and campaigning might increase political will among policy makers to act. Second, studies on public participation in policy making, as described earlier, identify outcomes that strengthen democracies, independent of the specific policies adopted. These include legitimization of the policy making process through broader input and support for adopted policies (Bryson \& Anderson, 2000; Smith \& Huntsman, 1997; Xu, 2001), more effective polices (Kastens \& Newig, 2008), and broader distribution of policy benefits among stakeholders (Gallagher \& Jackson, 2008). For some policy advocates, these democratic outcomes may be as important, if not more so, as specific policies.

[Figure 1 about here]

\section{Discussion}

The conceptual framework we propose in this paper follows the lead of the practitioner literature by presenting the inputs, activities, and outcomes of policy advocacy, and theoretical 
linkages among them, in the format of a logic model (Figure 1). Having identified logic models from the practitioner literature, and combined like elements to create a combined logic model, we then identified theories suggesting that certain inputs enable various kinds of activities, and that certain activities may lead to various types of outcomes, resulting in a conceptual framework. Our applications found that current theories, primarily drawn from theories of the policy process, support connections between most of the elements identified in practitioner logic models. The absence of linkages in our figure between certain inputs, activities, and outcomes does not presume that connections are lacking, it simply means that our literature review did not identify theory that supports such connections.

Even so, our logic model clearly suggests some hypothesized patterns of policy advocacy that may be empirically tested. At least two broad goals of advocacy are identified in the logic model, and perhaps five strategies of advocacy. See Figures $2 \mathrm{a}-2 \mathrm{e}$. The first goal-promoting public-centered policy making - appears to take an appropriate strategy that is rooted in public action (Figure 2a.). Its key inputs include people and relationships, and its activities are in engaging and mobilizing the public. These activities do not aim for specific policy outcomes, but instead are meant to build the political influence of a group or the public in the policy making process, thereby resulting in public policies that better represent their interests. The second goal—changes for target populations and the systems that serve them—appears to have four distinct strategies for advocacy. Two of these are focused on the power of legislators, executives, or other policy elites to make policy changes, but they differ in how they aim to influence these decision makers. The public pressure strategy (Figure 2b) engages several advocacy activities such as information campaigning, community organizing, and coalition building, to sway the public's views on policy issues. The change in public awareness or 
preferences then influences the decision makers' actions in adopting specific policy changes favorable to the engaged public. The variation on this strategy bypasses the proximal outcome of changing public views and instead attempts to directly influence decision makers' views (Figure 2c). Our review of the policy studies literature suggests that all of the advocacy activities in the logic model are used in this strategy, making it the most varied strategy identified here. Another strategy aimed at target population services and impacts takes a direct approach at policy change, bypassing legislative processes (Figure 2d). The direct reform strategy provides policy advocates a more critical role in policy change efforts, in lieu of the legislative and executive decision makers described above. For example, using litigation to reform policy requires an advocate/plaintiff with legal standing to initiate the judicial review. Similarly, direct ballot initiatives require advocates to advance the policy proposal to a referendum. These activities often require specialized knowledge and skills in the policy issue and judicial processes, which may limit its use among policy advocates. The last apparent strategy also bypasses legislative processes, but instead focuses on the implementation policy, rather than its adoption (Figure 2e). The implementation change strategy relies on policy monitoring activities to affect how policies are implemented, thereby affecting the goal for target population services and impacts. Like the direct reform strategy, changing how a policy is implemented also requires specialized knowledge and skills, especially in the areas of bureaucratic processes, policy interpretation, and policy adjudication.

These five strategies resulted from our linking of the composite logic model to relevant academic literature in policy studies, and they establish testable hypotheses for future empirical research. Such research would likely observe policy advocacy organizations and their actions, 
test for the practice of these strategies, and also look for other strategies that are not captured in this study.

[Figure 2 (Figures 2a-2e) about here]

\section{Limitations}

There were, however, some areas of the conceptual framework for which theory was lacking. In the connections between inputs and activities, theories supported several connections to activities such as coalition building, engaging the public, engaging decision makers, and information campaigning. However, the inputs needed to engage in activities such as reform efforts, defensive actions, and monitoring of the policy implementation process remain unclear. In the connections between activities and outcomes, a majority of activities are connected directly and indirectly to changes in decision makers' views, as these formal players are often necessary for policy change. However, the relative influences of these activities on decision makers' views is unknown and not hypothesized here. Also, no distinctions are made here on the types of decision makers that might be more influenced by one sort of advocacy activity over another. Instead, in this conceptual framework, they are all classified similarly. There is also an area in which the theory seems to be ahead of practice. Sabatier (1988) identified time for policy change as an important consideration, especially time for policy-relevant learning, and Linsky (1988) suggests that policy advocates can affect the time span for change. Yet the practitioner literature is mostly void of discussions of time, other than efforts to set the policy agenda to force policy considerations. These weaknesses of the combined logic model are all subjects for future empirical research. This conceptual framework simply provides an important context for their study. 
Our claims on the generalizability of this conceptual framework must also be articulated. While we have developed our initial combined logic model from advocacy organizations in varied policy arenas, there are three clear limitations of its applicability. First, as previously mentioned, our framework assumes a political and social context that is characterized by a democratic form of government that allows people to participate in processes such as shaping the policy agenda, expressing preferences for government actions, and voting with an assurance that everyone has an equal voice (Dahl, 1989). In such as system, policy advocacy functions as the people-initiated participation in the policy making process, in contrast to the governmentinitiated public participation process. In contrast, under authoritarian forms of governance, the political system is not constitutionally bound to public input into the policymaking process, and therefore the conceptual framework described in this article would not be applicable. Second, while an individual may independently engage in policy advocacy, the logic models that informed this research took the perspective of a group and assumed collective action. This conceptual framework cannot be assumed to apply to actions undertaken by an individual working on their own. Lastly, we reiterate that the academic theories that we have drawn upon were developed in varied fields, none of which was specifically policy advocacy organizations. We justified this activity, and this article, on the fact that policy advocacy simply lacks theoretical grounding. Nonetheless, our application of existing theories to this conceptual framework is an extrapolation outside of their original contexts, to hypothesize the relationships between advocacy inputs, activities, and outcomes. By doing so, we present direction for future research on policy advocacy.

\section{Conclusion}


Policy advocacy is an understudied field, with limited theory and empirical research. For example, in their comprehensive review of the interest group literature, Baumgartner and Leech (1998) concluded that the decline in interest group research in the 1970s was due not to actual changes in the political system, but to social scientists' methodological constraints in measuring interest groups' activities and outcomes. This study directly address this issue by hypothesizing a plausible conceptual framework for policy advocacy, based on practitioner literature and academic theories, that identifies measures for advocacy inputs, activities, and outcomes. Empirical research on these variables, and their perceived connections among them, is needed to substantiate or refute the hypothesized linkages of this conceptual model. Such research may help to guide the development of performance measures for the policy advocacy field, which would respond to the growing interest in policy advocacy evaluation, and address some of its inherent challenges, such as documenting progress (Morariu, 2009). Academically, such research would also help fill an increasingly critical gap in our understanding of processes of policy change, focusing on the necessary resources, activities, and efficacy of policy advocates. 


\section{References}

Arons, D. (2000). The meanings and actions of advocacy. The Nonprofit Quarterly, 7 (1-3), 7 9.

Bardach, E. (1977). The implementation game: What happens after a bill becomes a law. Cambridge, MA: MIT Press.

Bardach, E. (2000). A practical guide for policy analysis: The eightfold path to more effective problem solving ( $2^{\text {nd }}$ ed.). New York: Chatham House Publishers.

Baumgartner, F.R. \& Leech, B.L. (1998). Basic interests: The importance of groups in politics and in political science. Princeton, NJ: Princeton University Press.

Birkland, T. (1997). After disaster: Agenda setting, public policy, and focusing events. Washington, DC: Georgetown University Press.

Boak, G. (1991). Developing managerial competencies: The management learning contract approach. London: Pitman.

Bryson, J.M. \& Anderson, S.R. (2000). Applying large-group interaction methods in the planning and implementation of major change efforts. Public Administration Review, 60 (2), 143-153.

Burgoyne, J. (1988). Competency based approaches to management development. Lancaster: Centre for the Study of Management Learning.

Busch, C.B., Kirp, D.L. \& Schoenholz, D.F. (1998-9). Rights, politics, and expertise: Righting the balance. New York University Journal of Legislation and Public Policy 2 (2), 247-263.

Cahn, M.A. (1995). The players: Institutional and noninstitutional actors in the policy process. In S.Z. Theodoulou \& M.A. Cahn (Eds). Public policy: The essential readings (pp. 201-211). Englewood Cliffs, NJ: Prentice Hall, 
Center for Community Health and Evaluation. (N.D.). Measuring the impact of advocacy and policy efforts: Case study example. Retrieved from http://www.civicpartnerships.org/docs/services/OLE/2010OLEConfPresentations/CCP\%20C onf_VGC\%20Eval\%20Worksheet\%20.pdf

Chapman, J. \& Wameyo, A. (2001). Monitoring and evaluating advocacy: A scoping study. Action Aid. Retrieved from: http://www.actionaid.org/assets/pdf/Scoping\%20advocacy\%20paper\%202001.pdf

Child, C.D. \& Gronbjerg, K.A. (2007). Nonprofit advocacy organizations: Their characteristics and activities. Social Science Quarterly, 88 (1), 259-281.

Coffman, J., Hendricks, A., Kaye, J.W., Kelly, T., \& Masters, B. (2007). The advocacy and policy change composite logic model. Seattle, WA: Advanced Practice Institute conducted at the 58th Annual Conference of the Council on Foundations. Retrieved from: http://www.gse.harvard.edu/hfrp/eval/issue34/index.html

Cooper, H.M. (1988). Organizing knowledge synthesis: A taxonomy of literature reviews. Knowledge in Society, 1, 104-126.

Cress, D.M. \& Snow, D.A. (1996). Mobilization at the margins: Resources, benefactors, and the viability of homeless social movement organizations. American Sociological Review, 61, 1089-1109.

Dahl, R.A. (1967). Pluralist democracy in the United States: Conflict and consent. Chicago: Rand McNally \& Company.

Dahl, R.A. (1989). Democracy and its critics. New Haven: Yale University Press. deLeon, P. (1992). The democratization of the policy process. Public Administration Review, 52 (2), 125-129. 
Denhardt, R.B. and Denhardt, J.V. (2000). The new public service: Serving rather than steering. Public Administration Review, 60 (6): 549-559.

DeVita, C.J., Montilla, M., Reid, B. and Fatiregun, O. (2004). Organizational factors influencing advocacy for children. Washington, D.C.: Center on Nonprofits and Philanthropy, The Urban Institute.

Edelman, M.J. (1964). The symbolic uses of politics. Champaign, IL: University of Illinois Press. Elmore, R.F. (1979). Backward mapping: Implementation research and policy decisions. Political Science Quarterly, 80, 601-616.

Epstein, L., Kobylka, J.F., \& Stewart, J.F. (1995). A theory of interest groups and litigation. In S. Nagel (Ed.), Research in law and policy studies. Greenwich, CT: JAI Press.

Fagen, M.C., Reed, E., Kaye, J.W., \& Jack, L. (2009). Advocacy evaluation: What it is and where to find out more about it. Health Promotion Practice, 10, 482-484.

Frederickson, H.G. (1982). The recovery of civism in public administration. Public Administration Review, 42 (6), 501-507.

Gallagher, D.R. \& Jackson, S.E. (2008). Promoting community involvement at brownfields sites in socio-economically disadvantaged neighborhoods. Journal of Environmental Planning \& Management, 51 (5), 615-630.

Gladwell, M. (2010, Oct. 4). Small change: Why the revolution will not be tweeted. The New Yorker.

Glaser, B. \& and Strauss, A. (1967). The discovery of grounded theory: Strategies for qualitative research. New York: Aldine Publishing Company.

Granovetter, M. (1973, May). The strength of weak ties. American Journal of Sociology, 78, 1360-1380. 
Grantmakers In Health (2005, February). Funding health advocacy, Washington, D.C.: GIH Issue Brief No. 21.

Guthrie, K., Louise, J., David, T., \& Foster, C.C. (2005, October). The challenge of assessing policy and advocacy activities: Strategies for a prospective evaluation approach. Prepared by Blueprint Research \& Design, Inc. for the California Endowment.

Herman, E. \& Chomsky, N. (2002). Manufacturing consent: The political economy of the mass media. New York: Pantheon.

Hill, M. \& Hupe, P. (2011). Implementing public policy (2 $2^{\text {nd }}$ ed.). London: Sage.

Hoefer, R. (2011). Advocacy practice for social justice (2 ${ }^{\text {nd }}$ ed.). Chicago, IL: Lyceum Books, Inc.

Hoffmann, T. (1999). The meanings of competency. Journal of European Industrial Training, $23(6), 275-286$.

Hopkins, B.R. (1992). Charity, advocacy and the law. New York: Wiley.

Morariu, J., Reed, E., Brennan, K., Stamp, A., Parrish, S., Pankaj, V., \& Zandniapour, L. (2009). Pathfinder evaluation edition: A practical guide to advocacy evaluation. Innovation Network, Inc. Retrieved from http://www.innonet.org/index.php?section_id=3\&content_id=601

Iyengar, S. \& Kinder, D. (1987). News that matters. Chicago: University of Chicago Press. Jansson, B. (2010). Becoming an effective policy advocate: From policy practice to social justice $\left(5^{\text {th }}\right.$ ed.). Belmont, CA: Thomson Brooks/Cole.

Jenkins, J.C. (1987). Nonprofit organizations and policy advocacy. In W.W. Powell (Ed.), The nonprofit sector: A research handbook (pp. 296-315). New Haven, CT: Yale University Press. 
Jones, M.D. \& McBeth, M.K. (2010). A narrative policy framework: Clear enough to be wrong? Policy Studies Journal, 38 (2), 329-353.

Jubb, R. \& Robotham, D. (1997). Competences in management development: Challenging the myths. Journal of European Industrial Training, 21 (5), 171-5.

Kagan, R.A. (1998-9). Adversarial legalism: Tamed or still wild? New York University Journal of Legislation and Public Policy, 2(2), p. 217-245.

Kagan, R.A. (1991). Adversarial legalism and American government. Journal of Policy Analysis and Management, 10 (3), 369-406.

Kastens, B. \& Newig, J. (2008). Will participation foster the successful implementation of the water framework directive? The case of agricultural groundwater protection in Northwest Germany. Local Environment, 13(1), 27-41.

Kingdon, J.W. (1984). Agendas, alternatives and public policies. New York: Longman.

Knowlton, L.W. \& Phillips, C.C. (2009). The logic model guidebook: Better strategies for great results. Los Angeles: Sage Publications.

Koenig, H.O. (2005). Empowerment in local government administration: The case of Elgin, Illinois. The Innovation Journal: The Public Sector Innovation Journal, 10 (1).

Lindblom, C. (1959). The science of muddling through. Public Administration Review, 19 (spring), 79-88.

Lindblom, C.E. \& Cohen, D.K. (1979). Usable knowledge: Social science and social problem solving. New Haven: Yale University Press.

Linsky, M. (1988). Impact: How the press affects federal policy making. New York: W. W. Norton \& Company. 
Lipsky, M. (2010). Street-level bureaucracy: Dilemmas of the individual in public services $\left(30^{\text {th }}\right.$ anniversary expanded ed.). New York: Russell Sage.

Majone, G. (1989). Evidence, argument and persuasion in the policy process. New Haven: Yale University Press.

McAdam, D. (1982). Political process and the development of Black insurgency, 1930-1970. Chicago: University of Chicago Press.

McCarthy, J.D. \& Zald, M.N. (1977). Resource mobilization and social movements: A partial theory. American Journal of Sociology, 82, 1212-1241.

McCarthy, J.D. \& Zald, M.N. (2002). The enduring vitality of the resource mobilization theory of social movements. In J.H. Turner (Ed.), Handbook of sociological theory (pp. 533-565). New York: Kluwer Academic/Plenum Publishers.

McLaverty, P. 2011. Participation. In M. Bevir (Ed.), The Sage handbook of governance (pp. 402-417). Thousand Oaks, CA: Sage Publications.

Mills, C. (1956). The power elite. New York: Oxford University Press. Moore, S. (2011). Can public-policy advocacy be taught? Or learned? The Philanthropist, 23 (4), $471-480$

Nachmias, D. (1980). The role of evaluation in public policy. Policy Studies Journal, 8, 11631169.

Nalbandian, J. (1999). Facilitating community, enabling democracy: New roles for local government managers. Public Administration Review, 59 (3), 187-197.

Nowlin, M.C. (2011). Theories of the policy process: State of the research and emerging trends. Policy Studies Journal, 39 (S1), 41-60. 
Olson, M. (1965). The logic of collective action: Public goods and the theory of groups. Cambridge, MA: Harvard University Press.

Ostrom, E. (1999). Institutional rational choice: An assessment of the institutional analysis and development framework. In P.A. Sabatier (Ed.), Theories of the policy process (pp. 35-71), Boulder, CO: Westview Press.

Perkins, D.D. \& Zimmerman, M.A. (1995, Oct.). Empowerment theory, research, and application. American Journal of Community Psychology, 23 (5), 569-579.

Portes, A. (1998). Social capital: Its origins and applications in modern sociology. Annual Review of Sociology 24, 1-24.

Pressman, J.L. \& Wildavsky, A.B. (1984). Implementation: How great expectations in Washington are dashed in Oakland; or, why it's amazing that federal programs work at all, this being a saga of the economic development administration as told by two sympathetic observers who seek to build morals on a foundation of ruined hopes. Berkeley, CA: University of California Press.

Putnam, R.D. (1976). The comparative study of political elites. Upper Saddle River, NJ: Prentice Hall.

Putnam, R. (2000). Bowling alone: The collapse and revival of American Community. New York: Simon \& Schuster.

Ramet, S. (1992, Fall). Balkan pluralism \& its enemies. Orbis, 36 (4), 547-564

Rappaport, J. (1981). In praise of paradox: A social policy of empowerment over prevention. American Journal of Community Psychology, 9 (1), 1-25. 
Rappaport, J., Davidson, W.S., Wilson, M.N., Mitchell, A. (1975). Alternatives to blaming the victim or environment: Our places to stand have not moved the earth. American Psychologist, 30, p. 525-528.

Reid, E.J. (2001). Understanding the word 'advocacy': Context and use. In Nonprofit advocacy and the policy process: Structuring the inquiry into advocacy (pp. 1-7), Volume 1, Washington, DC: The Urban Institute.

Reisman, J., Gienapp, A., \& Stachowiak, S. (2007). A guide to measuring advocacy and policy. Prepared by Organizational Research Services for Annie E. Casey Foundation.

Rietbergen-McCracken, J. (n.d.) Participatory policy making. Retrieved from: http://pgexchange.org/images/toolkits/PGX_F_ParticipatoryPolicy\%20Making.pdf

Riley, D.D. \& Brophy-Baermann, B.E. (2006). Bureaucracy and the policy process: Keeping the promises. Lanham, MD: Rowman \& Littlefield.

Rowe, C. (1995). Clarifying the use of competence and competency models in recruitment, assessment and staff development, Industrial and Commercial Training, 27 (11), 12-17.

Sabatier, P.A. (1999). The need for better theories. In P.A. Sabatier (Ed.), Theories of the Policy Process (pp. 3-18). Boulder, CO: Westview Press.

Sabatier, P.A. (1988). An advocacy coalition framework of policy change and the role of policyoriented learning therein. Policy Sciences, 21, 129-168.

Sabatier, P.A. \& Jenkins-Smith, H.C. (1999). The Advocacy Coalition Framework: An assessment. In P.A. Sabatier (Ed.), Theories of the Policy Process (pp. 117-166). Boulder, CO: Westview Press. 
Saidel, J.R. (2002). Nonprofit organizations, political engagement, and public policy. In E.J. Reid \& Montilla, M.D. (Eds.), Exploring organizations and advocacy governance and accountability (pp. 1-18). Washington, D.C.: Urban Institute.

Schlozman, K.L. \& Tierney, J.T. (1986). Organized interests and American democracy. New York: Harper \& Row.

Schmid, H., Bar, M. \& Nirel, R. (2008). Advocacy activities in nonprofit human service organizations: Implications for policy. Nonprofit and Voluntary Sector Quarterly, 37, 581602.

Schneider, A.L. \& Ingram, H.M. (1993). Social construction of target populations: Implications for politics and policy. The American Political Science Review, 87 (2), 334-347.

Simon, H. (1945). Administrative behavior: A study of decision making processes in administrative organizations. Mankato, MN: The Free Press.

Smith, G.E. \& Huntsman, C.A. (1997). Reframing the metaphor of citizen-government relationship: A value-centered perspective. Public Administration Review, 57 (4), 309-318.

Sprechmann, S. \& Pelton, E. (2001, January). Advocacy tools and guidelines: Promoting policy change. A resource manual for CARE program managers. Retrieved from http://www.care.org/getinvolved/advocacy/tools/english_00.pdf

Strebler, M., Robinson, D., and Heron, P. (1997). Getting the best out of your competencies, Institute of Employment Studies, University of Sussex, Brighton.

Stone, D.A. (2002). Policy paradox: The art of political decision making (Revised ed.). New York: W.W. Norton \& Company.

Tate, W. (1995). Developing managerial competence: A critical guide to methods and materials, London: Gower. 
Theodoulou, S. \& Kofinis, C. (2004). The art of the game: Understanding American public policy making. Belmont, CA: Thomson Wadsworth.

Tilly, C. (1978). From mobilization to revolution. New York: McGraw-Hill.

Truman, D. (1993). The governmental process: Political interests and public opinion ( $2^{\text {nd }}$ ed.). Berkeley, CA: University of California Press.

Walker, J.L. (1966). A critique of the elitist theory of democracy. American Political Science Review, 60, 285-295.

Weible, C., Sabatier, P., Jenkins-Smith, H., Nohrstedt, D., Henry, A.D., \& deLeon. P. (2011). A quarter century of the Advocacy Coalition Framework: An introduction to the special issue. Policy Studies Journal, 39 (3), 349-360.

Weimer, D.L. \& Vining, A.R. (1992). Policy analysis: Concepts and practice (2 $2^{\text {nd }}$ ed.). Englewood Cliffs, NJ: Prentice Hall.

Weiss, C.H. \& Bucuvalas, M.J. (1980). Truth tests and utility tests: Decision-makers' frames of reference for social science research. American Sociological Review, 45 (2), 302-313.

Woodruffe, C. (1991). Competent by any other name. Personnel Management, 23 (9), 30-3.

Xu, J. (2005). Why do minorities participate less? The effects of immigration, education, and electoral process on Asian American voter registration and turnout. Social Science Research, $34,682-702$.

Zimmerman, M.A. (1995). Psychological empowerment: Issues and illustrations. American Journal of Community Psychology, 23 (5), 581-599.

Zimmerman, M.A. (2000). Empowerment theory: Psychological, organizational, and community levels of analysis. In J. Rappaport \& E. Seidman (Eds.), Handbook of community psychology (pp. 43-63). New York: Kluwer Academic/Plenum. 
Table 1: Composite theory of change for policy advocacy

\begin{tabular}{|c|c|c|c|c|}
\hline $\begin{array}{l}\text { INPUTS/ } \\
\text { COMPETENCIES }^{1} \\
\text { (necessary conditions) }\end{array}$ & $\begin{array}{l}\text { ACTIVITIES } \\
\text { (things to do, actions) }\end{array}$ & $\begin{array}{l}\text { PROXIMAL } \\
\text { OUTCOMES } \\
\text { (indirect and near-term) }\end{array}$ & $\begin{array}{l}\text { DISTAL } \\
\text { OUTCOMES } \\
\text { (indirect and long term) }\end{array}$ & IMPACTS \\
\hline $\begin{array}{l}\text { - Sense of 'agency' in the } \\
\text { political process (AA) as } \\
\text { manifested by } \\
\circ \text { Sense of empowerment and } \\
\text { political power' } \\
\circ \text { Will to challenge status quo } \\
\circ \text { Ability to identify and } \\
\text { define problems } \\
\text { - People and Relationships } \\
\text { (AA, CCHE, HFRP, GH) } \\
\text { ○ Leadership } \\
\circ \text { Staffing } \\
\circ \text { Ability to organize } \\
\text { collective action } \\
\circ \text { Strategic partnerships } \\
\text { - Specialized knowledge and } \\
\text { skills (AA, CCHE, HFRP, } \\
\text { GH): } \\
\circ \text { Strategy } \\
\circ \text { Research } \\
\circ \text { Media } \\
\circ \text { Public relations } \\
\circ \text { Lobbying } \\
\text { - Material resources (CCHE, } \\
\text { HFRP, GH) } \\
\circ \text { Financial }\end{array}$ & $\begin{array}{l}\text { - Coalition building (CCHE, AA, GH, AEC, PF) } \\
\text { ○ Networking } \\
\text { ○ Forming coalitions/Federations } \\
\text { - Engaging and mobilizing the public (AEC, GH, } \\
\text { HFRP, CCHE, AA) } \\
\circ \text { Community organizing, outreach } \\
\circ \text { Voter registration } \\
\text { ○ Rallies, convenings, protests, writing letters } \\
\text { - Engaging decision makers (CCHE, HFRP, AA, PF, } \\
\text { GH) } \\
\text { ○ Lobbying } \\
\circ \text { Relationship building } \\
\text { - Information campaigning (CCHE, HFRP, AA, GH, } \\
\text { AEC) } \\
\circ \text { Research, policy analysis, white papers } \\
\circ \text { Refining and framing message; labeling } \\
\text { ○ Education } \\
\circ \text { Briefings, presentations } \\
\circ \text { Media advocacy } \\
\text { - Reform efforts (HFRP, GH, AEC, PF) } \\
\circ \text { Pilots, demonstrations } \\
\circ \text { Litigation } \\
\text { - Defensive activities (PF, AEC) } \\
\circ \text { Read and react to opponents } \\
\text { ○ Read and react to climate } \\
\text { - Policy monitoring (HFRP, GH, AEC) } \\
\circ \text { Evaluation }\end{array}$ & $\begin{array}{l}\text { - Democratic environment } \\
\text { (AA) } \\
\circ \text { Governance: } \\
\text { Transparency/ } \\
\text { accountability improved } \\
\circ \text { Civil society: Power and } \\
\text { capacity enhanced } \\
\text { - Changes in public views } \\
\text { (CCHE, HFRP, AA, AEC) } \\
\circ \text { Changes in awareness, } \\
\text { beliefs, attitudes, values, } \\
\text { salience of issues, } \\
\text { behaviors } \\
\circ \text { Strengthened base of } \\
\text { support: increased public } \\
\text { involvement, levels of } \\
\text { action } \\
\text { - Changes in decision makers' } \\
\text { views (CCHE, HFRP, AEC, } \\
\text { PF) } \\
\circ \text { Getting on political agenda } \\
\text { O Political will }\end{array}$ & $\begin{array}{l}\text { Policy adoption (CCHE, } \\
\text { HFRP, AA, AEC) } \\
\circ \text { Changed, improved policy } \\
\text { ○ Policy blocking } \\
\\
\text { - Implementation change } \\
\text { (HFRP, AA, AEC, GH) } \\
\text { ○ Improved implementation } \\
\text { ○ Policy enforcement }\end{array}$ & $\begin{array}{l}\text { - Desired changes for target } \\
\text { population (CCHE, HFRP, } \\
\text { AA, AEC) } \\
\text { - Desired changes in services } \\
\text { and systems (HFRP) } \\
\text { - People-centered policy } \\
\text { making (AA) }\end{array}$ \\
\hline
\end{tabular}

${ }^{1}$ Group or individual level

${ }_{3}^{2}$ Excluded agency-specific goals (e.g., increased funding, collaboration, recognition) as not central to policy advocacy mission.

${ }^{3}$ Sub-bullets are examples of the items in the major bullets; they are not comprehensive lists

Abbreviations:

AA: Chapman, Jennifer \& Wameyo, Amboka. 2001. Monitoring and Evaluating Advocacy: A Scoping Study. Action Aid. 55 pages

AEC: Reisman, Jane; Gienapp, Anne; \& Stachowiak, Sarah. 2007. A Guide to Measuring Advocacy and Policy. Baltimore, The Annie E. Casey Foundation.. 38 pages.

CCHE: Center for Community Health and Evaluation. N.D. Measuring the Impact of Advocacy and Policy Efforts: Case Study Example. Center for

Community Health and Evaluation.

GH: Grantmakers in Health. 2005. Funding Health Advocacy, Issue Brief No. 21. Grantmakers in Health. 
HFRP: Coffman, Julia. 2007. Using the Advocacy and Policy Change Composite Logic Model to Articulate an Advocacy Strategy or Theory of Change. Harvard Family Research Project.

PF: Morariu, Johanna; Reed, Ehren; Brennan, Kathy; Stamp, Andy; Parrish, Simone; Pankaj, Veena; \& Zandniapour, Lily. 2009. Pathfinder: A Practical Guide to Advocacy Evaluation. Washington, DC: Innovation Network, Inc. 10 pages. 
Table 2: Theoretical links among inputs, activities, outcomes and impacts

\begin{tabular}{|c|c|c|}
\hline Inputs & Theoretical link & Activities \\
\hline $\begin{array}{l}\text { Sense of 'agency' in the political } \\
\text { process }\end{array}$ & Empowerment theory & $\begin{array}{l}\text { Coalition building; Engaging and } \\
\text { mobilizing the public }\end{array}$ \\
\hline Specialized knowledge and skills & Competency & All \\
\hline People and relationships & Social capital theory & $\begin{array}{l}\text { Coalition building; Engaging and } \\
\text { mobilizing the public }\end{array}$ \\
\hline Material resources & Resource mobilization theory & $\begin{array}{l}\text { Coalition building; Engaging } \\
\text { decision makers; Information } \\
\text { campaigning }\end{array}$ \\
\hline Activities & Theoretical link & Outcomes and impacts \\
\hline $\begin{array}{l}\text { Coalition building; } \\
\text { Engaging and mobilizing the public; } \\
\text { Information campaigning }\end{array}$ & $\begin{array}{l}\text { Advocacy coalition framework; } \\
\text { interest group studies }\end{array}$ & $\begin{array}{l}\text { Changes in public views; Changes in } \\
\text { decision makers' views; Policy } \\
\text { adoption }\end{array}$ \\
\hline Engaging decision makers & Institutionalism; Elite theory & $\begin{array}{l}\text { Changes in decision makers' views; } \\
\text { Policy adoption }\end{array}$ \\
\hline $\begin{array}{l}\text { Information campaigning: research } \\
\text { and analysis }\end{array}$ & Rational decision making & $\begin{array}{l}\text { Changes in public views; Changes in } \\
\text { decision makers' views; Policy } \\
\text { adoption }\end{array}$ \\
\hline $\begin{array}{l}\text { Information campaigning: rhetoric } \\
\text { (e.g., issue framing, labeling, } \\
\text { anecdotes, etc.) }\end{array}$ & Rhetoric studies & $\begin{array}{l}\text { Changes in public views; Changes in } \\
\text { decision makers' views; Policy } \\
\text { adoption }\end{array}$ \\
\hline $\begin{array}{l}\text { Information campaigning: media } \\
\text { work }\end{array}$ & Media studies & $\begin{array}{l}\text { Changes in public views; Changes in } \\
\text { decision makers' views; Sets policy } \\
\text { agenda; Raises political will to act; } \\
\text { Shortens time frame for action }\end{array}$ \\
\hline Reform efforts: litigation & Adversarial legalism & Policy adoption \\
\hline $\begin{array}{l}\text { Reform efforts: pilots, } \\
\text { demonstrations }\end{array}$ & Incrementalism & $\begin{array}{l}\text { Changes in public views; Changes in } \\
\text { decision makers' views; Policy } \\
\text { adoption }\end{array}$ \\
\hline Defensive activities & $\begin{array}{l}\text { Public dialectic } \\
\text { Policy-oriented learning }\end{array}$ & $\begin{array}{l}\text { Changes in public views; Changes in } \\
\text { decision makers' views }\end{array}$ \\
\hline Policy monitoring & Bottom-up implementation theories & Changes in bureaucrats' actions \\
\hline Policy monitoring & Evaluation theory & Setting the policy agenda \\
\hline $\begin{array}{l}\text { Information campaigning; Engaging } \\
\text { and mobilizing the public; Engaging } \\
\text { decision makers }\end{array}$ & Multiple streams theory & $\begin{array}{l}\text { Setting the policy agenda; Policy } \\
\text { adoption }\end{array}$ \\
\hline Engaging and mobilizing the public & Public participation & $\begin{array}{l}\text { Democratic environment; People- } \\
\text { centered policy making }\end{array}$ \\
\hline
\end{tabular}


Figure 1: Hypothesized links ${ }^{1}$ within the policy advocacy logic model

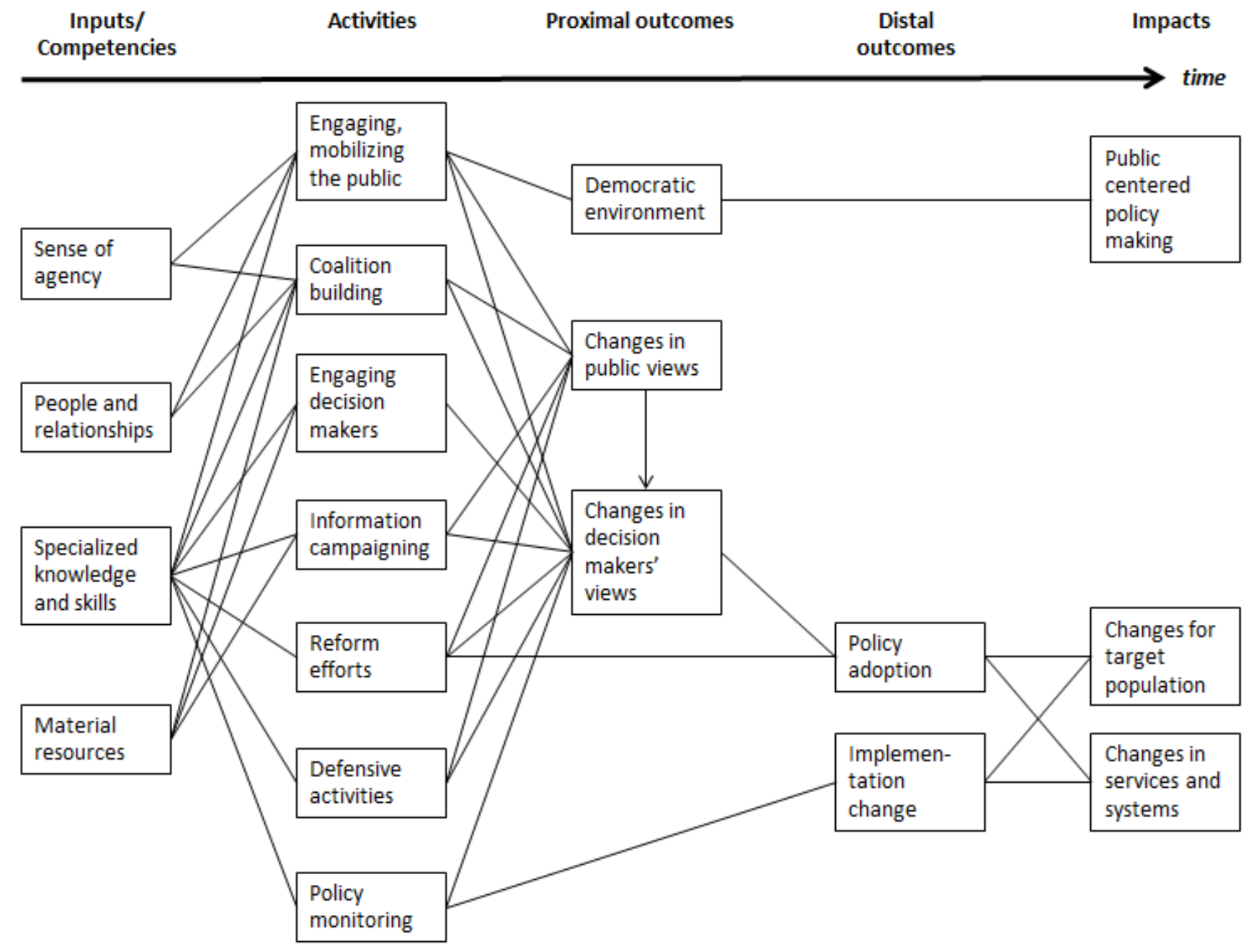

1. Linkages between elements of the logic model are from left to right, as indicated by the timeline above the logic model, except for the link between "Changes in public views" and "Changes in decision makers' views." For visual clarity, arrowheads were removed from the individual linkages. 
Figure 2: Hypothesized advocacy strategies

2a: Enhanced democratic environment

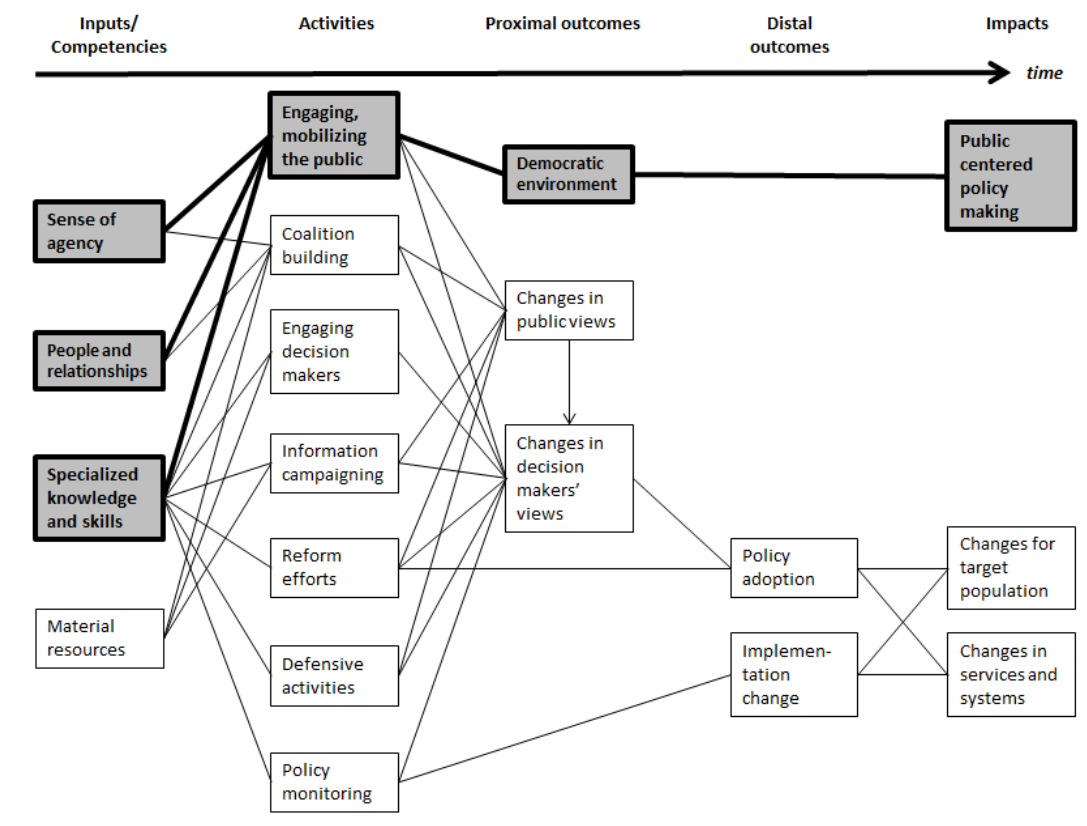

2b: Public pressure

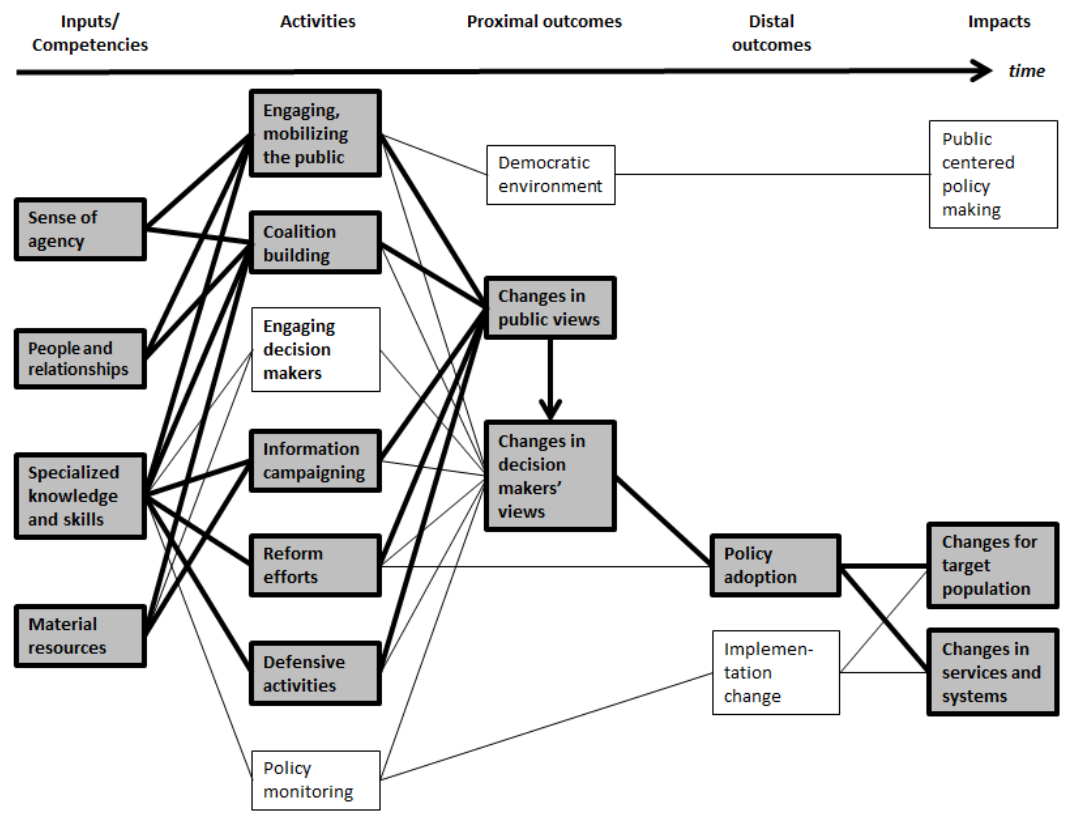


2c: Decision makers

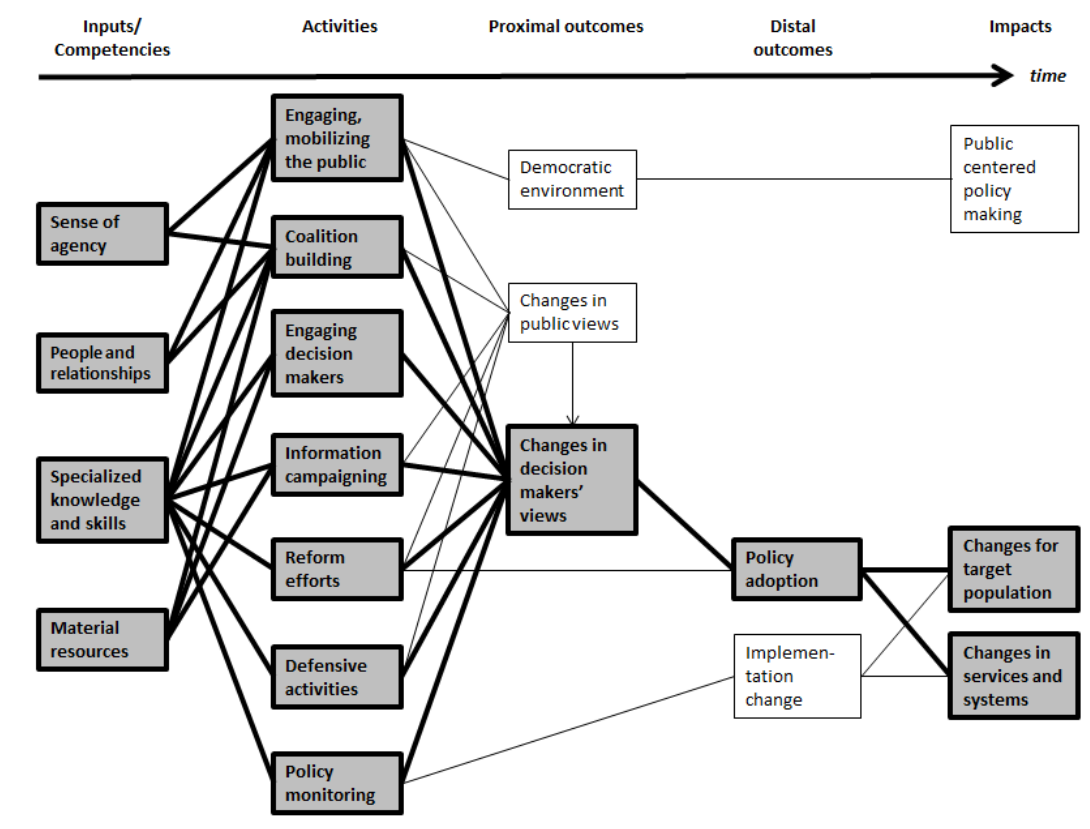

2d: Direct reform

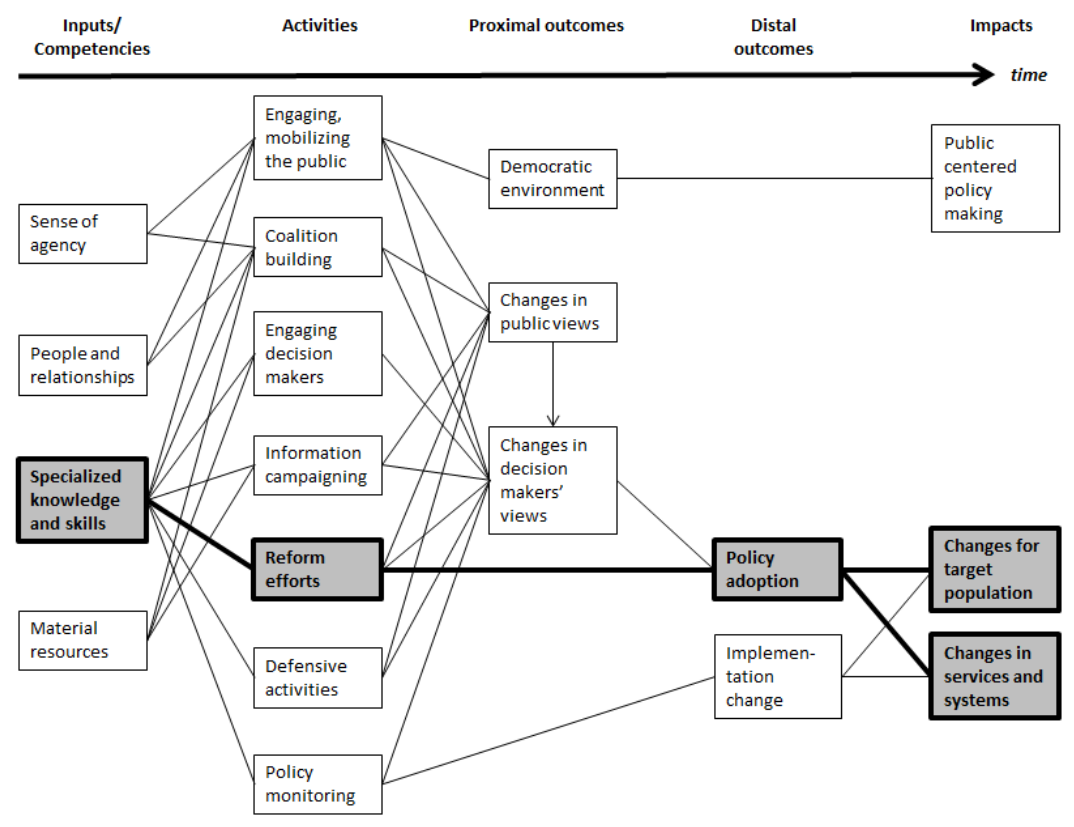


2e: Implementation change

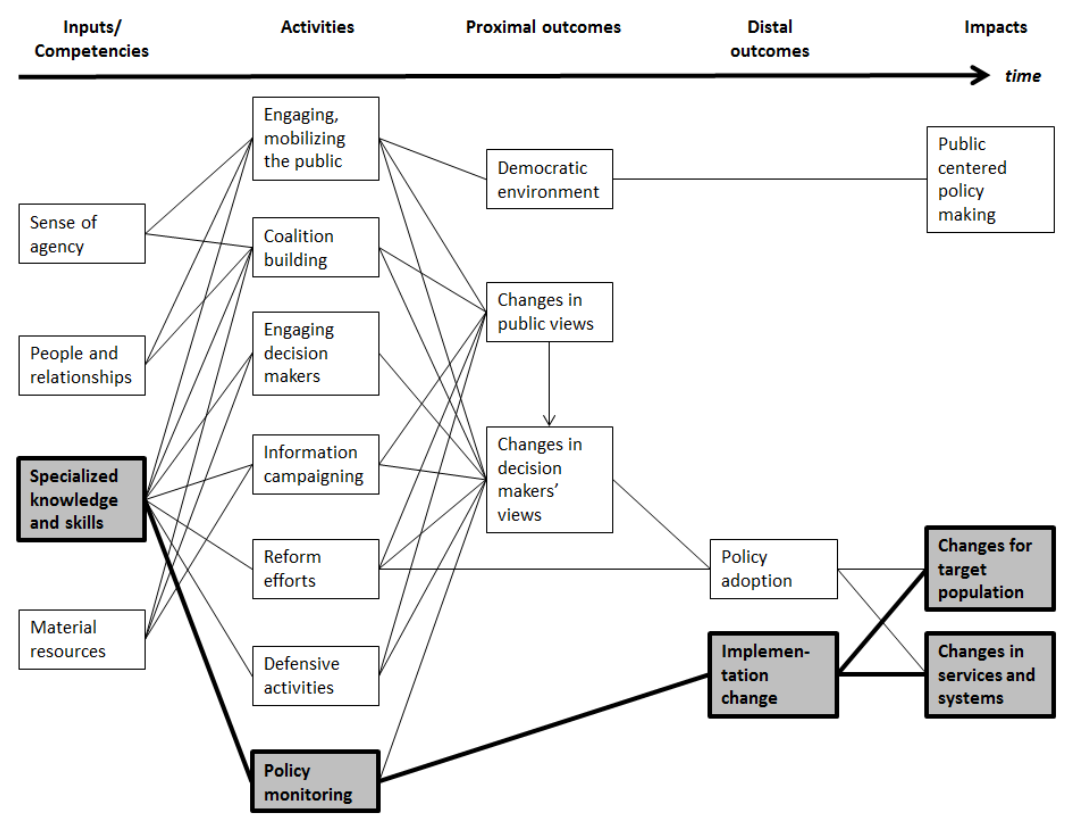

